\title{
PERBEDAAN TEKNIK PEMASANGAN TOURNIQUET TERHADAP KADAR KALIUM SERUM
}

\section{THE DIFFERENCES APPLICATION TECHNIQUE OF TOURNIQUET TO POTASSIUM LEVEL IN SERUM}

\author{
Bastian $^{1}$, FD Anindita Marson'2, Asmarani ${ }^{3}$, Pariyana ${ }^{4}$ \\ 1STIKes Muhamadiyah Palembang, \\ ${ }^{2}$ ATLM RS Charitas Bengkulu \\ ${ }^{3}$ FK. Universitas Muhammadiyah Palembang \\ ${ }^{4}$ FK. Universitas Sriwijaya \\ Email: bastiandarwin51@yahoo.com
}

DOI : 10.24252/kesehatan.v11i2.6328

\begin{abstract}
Abstrak
Kalium adalah analit yang penting karena jika ada kekurangan atau terlalu banyak kalium, itu akan menyebabkan kematian seseorang, itulah alasan mengapa kesalahan dalam pengukuran kalium dapat membuat kondisi serius bagi pasien jika terapi berdasarkan pada hasil laboratorium tidak akurat. Keadaan hemokonsentrasi sampel dapat mempengaruhi hasil akhir yang diperoleh. Penelitian ini bertujuan untuk mengetahui teknik aplikasi Tourniquet terhadap kadar kalium, dimana penggunaan Tourniquet yang kurang tepat juga dapat menyebabkan hemokonsentrasi sampel yang dapat meningkatkan kadar kalium dalam serum. Penelitian ini adalah eksperimental laboratorium yang menggunakan serum dari subjek. Semua data kemudian diolah secara statistik dengan T- Test berpasangan. Hasil penelitian adalah rata-rata kadar kalium dengan teknik Tourniquet yang dilepaskan tepat setelah vena dapat diakses adalah sekitar 3,86 mmol / L, lebih rendah dari intervensi kedua yang menggunakan aplikasi Tourniquet yang tidak dilepaskan sampai volume darah cukup, sekitar 4,05 mmol / L. Menurut hasil Uji T berpasangan, nilai p adalah 0,003 dengan signifikansi 2 tailed $(\alpha=0,025)$ yang membuat $p<\alpha$. Hasil ini menunjukkan bahwa ada perbedaan kadar potasium antara dua teknik aplikasi turniket
\end{abstract}

\section{Kata Kunci: Kalium Serum, Tourniquet}

\section{Abstract}

Potassium is an analyte that important because if there is a lack or too much potassium, it will causes someone is death, that is the reason why is the fault in measurement of potassium can make a serious condition to the patient if the therapy based on the laboratory result is not accurate. This study aims to know the effect of application technique of Tourniquet to potassium level. This study was a laboratory experimental that using serum from the subject. All of the data then processed statistically with paired TTest. The result of the study was the mean of potassium level with Tourniquet application that released right after the vein can be accesed was about 3,86 mmol/L, lower than the second intervention that using Tourniquet application that not released until the volume of blood was enough, about 4,05 mmol/L. According to paired T Test result, $p$ value is 0.003 with significancy 2 tailed $(a=0.025)$ that makes $p<a$. 
This result show that there are differences of potassium level between two application technique of Tourniquet.

Keywords: Potassium Serum, Tourniquet

\section{PENDAHULUAN}

Pemeriksaan elektrolit adalah salah satu pemeriksaan yang biasa dilakukan dalam laboratorium klinik. Elektrolit berperan penting dalam tubuh manusia terutama karena hampir semua proses metabolisme tubuh manusia dipengaruhi oleh elektrolit (Sacher dan Pherson, 2004). Potensial elektrokimiawi membran sel dipelihara oleh elektrolit, sehingga akhirnya akan mempengaruhi fungsi saraf, otot, dan aktivitas sel seperti sekresi, kontraksi, dan berbagai proses metabolik lainnya (Sacher dan Pherson, 2004).

Pemeriksaan elektrolit yang sering diminta di laboratorium adalah pemeriksaan $\mathrm{Na}, \mathrm{K}$ dan $\mathrm{Cl}$. Hal ini dilakukan untuk menilai keseimbangan kadar elektrolit dalam tubuh. Kalium merupakan analit kimia yang penting karena kelainannya dapat segera mengancam nyawa, sehingga kesalahan pengukuran dapat menimbulkan konsekuensi serius apabila terapi yang dilakukan didasari pada hasil yang tidak akurat (Sacher dan Pherson, 2004).

Tahap yang dilalui dalam berbagai pemeriksaan laboratorium meliputi tahap pra analitik, tahap analitik dan tahap pasca analitik. Kesalahan yang sering terjadi pada pemeriksaan laboratorium klinik pada tahap pre analitik yaitu $32-75 \%$, analitik $13-32 \%$, sedangkan pasca analitik 9-31\% (Wolcott et al, 2008). Tahap pre analitik meliputi persiapan pasien, pengambilan spesimen, penerimaan spesimen, pengolahan, penyimpanan, dan pengiriman. Teknik pengambilan spesimen juga perlu diperhatikan dalam pemeriksaan kalium.

Tourniquet merupakan bahan mekanis yang fleksibel yang biasanya dibuat dari karet sintetis yang bisa meregang. Tujuan penggunaan bendungan ini adalah untuk fiksasi, pengukuhan vena yang akan diambil darahnya, juga untuk menambah tekanan vena yang akan diambil sehingga akan mempermudah proses penyedotan darah ke dalam spuit. Pembendungan pembuluh darah vena akan menyebabkan perubahan pada beberapa komponen dalam darah jika tourniquet dibiarkan lebih dari satu menit, maka pemasangan tourniquet harus sedemikian rupa agar mudah dilepaskan dengan satu tangan pada saat jarum sudah memasuki dinding vena (Kiswari, 2014).

Keadaan hemokonsentrasi dapat mempengaruhi hasil akhir yang didapatkan. Penggunaan tourniquet yang kurang tepat juga dapat menyebabkan hemokonsentrasi sampel. Pada praktiknya, petugas laboratorium lebih sering menggunakan bantuan tourniquet untuk pengambilan sampel. Penggunaan tourniquet juga bervariasi antar petugas laboratorium. Ada yang menggunakan tourniquet hanya sampai pada awal 
proses pengambilan darah, ada yang menggunakan tourniquet hingga proses pengambilan darah telah selesai.

\section{METODOLOGI PENELITIAN}

\section{a. Subyek dan Metode}

Jenis penelitian merupakan penelitian eksperimen laboratorium dengan menggunakan serum yang diperoleh dari subyek penelitian. Populasi penelitian berjumlah 53 orang, dengan kriteria inklusi mengisi informed consent dan tidak sedang mengkonsumsi obat obatan diuretic (tiazid, furosemid). Dari total populasi, sampel dipilih dengan menggunakan teknik simple random sampling dan diperoleh sejumlah 20 orang subyek penelitian. Lokasi penelitian bertempat di Laboratorium Kimia Klinik Fakultas Ilmu Kesehatan Universitas Katolik Musi Charitas Palembang dan Laboratorium Klinik RS Myria Palembang. Sampel darah diambil dengan menggunakan bantuan sphyogmomanometer sebagai pengganti tourniquet dengan perhitungan besar tekanan sebagai berikut:

\section{Tekanan sphygmomanometer $=$ \\ Tekanan sistolik + Tekanan diastolik}

\section{2}

Perlakuan pertama dilakukan pengambilan darah dengan menggunakan teknik pemasangan tourniquet yang dilepaskan setelah vena dapat diakses, dan perlakuan kedua dilakukan pengambilan darah dengan menggunakan teknik pemasangan tourniquet yang tidak dilepaskan hingga volume darah yang diinginkan tercapai.

\section{b. Alat dan Bahan}

Alat yang digunakan dalam penelitan ini adalah: a) Spuit $3 \mathrm{cc}$; b) tourniquet/ sphygmomamometer; c) Kapas; d) Tabung vacutainer; e) Pipet mikro $500 \mu l$; f) Blue tip; g) Rak/ tempat tabung; h) Sentrifuge; i) cup serum; j) EasyLyte $\mathrm{Na} / \mathrm{K} / \mathrm{Cl}$ Analyzer. Bahan pemeriksaan yang digunakan dalam penelitian ini adalah darah vena, yang dibiarkan membeku sempurna (15-30 menit) kemudian diambil serumnya, dan segera di periksa menggunakan analyzer.

\section{c. Cara Kerja}

Subyek penelitian terpilih diukur tekanan darahnya untuk mengetahui besar tekanan pembendungan saat pengambilan darah. Subyek kemudian diambil darahnya sebanyak dua kali pada masing masing lengan dengan dua perlakuan yang berbeda. Pada lengan pertama, ketika darah sudah masuk spuit, tekanan sphygmomanometer dilepaskan, dan pengambilan darah tetap dilanjutkan hingga volume mencapai 3 cc. Pada lengan kedua, tekanan sphygmomanometer dipertahankan hingga volume 
mencapai 3cc. Kedua perlakuan ini diperhatikan waktunya agar pemasangan sphygmomanometer tidak melebihi 1 menit. Darah yang sudah diperoleh kemudian di sentrifus untuk memperoleh serum yang kemudian diperiksa kadar kaliumnya.

\section{HASIL DAN PEMBAHASAN}

\section{a. Hasil}

Sebanyak 20 data yang diperoleh pada perlakuan pertama (tourniquet yang dilepas) memiliki rata rata sebesar $3,86 \mathrm{mmol} / \mathrm{L}$ dengan nilai terendah pada $3,36 \mathrm{mmol} / \mathrm{L}$ dan nilai kalium tertinggi sebesar $4,19 \mathrm{mmol} / \mathrm{L}$. Perlakuan kedua (tourniquet yang tidak dilepas) memiliki rata rata kadar kalium sebesar $4,05 \mathrm{mmol} / \mathrm{L}$ dengan nilai terendah pada 3,64 mmol/L dan nilai tertinggi pada $4,54 \mathrm{mmol} / \mathrm{L}$

\begin{tabular}{|c|c|c|}
\hline $\begin{array}{l}\text { Kode } \\
\text { sample }\end{array}$ & $\begin{array}{l}\text { Kadar kalium dengan } \\
\text { Tourniquet dengan } \\
\text { dilepaskan }(A)\end{array}$ & $\begin{array}{l}\text { Kadar kalium dengan } \\
\text { Tourniquet tidak } \\
\text { dilepaskan (B) }\end{array}$ \\
\hline 1 & 3,66 mmol/L & $3,80 \mathrm{mmol} / \mathrm{L}$ \\
\hline 2 & $3,58 \mathrm{mmol} / \mathrm{L}$ & $4,09 \mathrm{mmol} / \mathrm{L}$ \\
\hline 3 & $3,73 \mathrm{mmol} / \mathrm{L}$ & $4,17 \mathrm{mmol} / \mathrm{L}$ \\
\hline 4 & $3,97 \mathrm{mmol} / \mathrm{L}$ & $3,87 \mathrm{mmol} / \mathrm{L}$ \\
\hline 5 & $3,99 \mathrm{mmol} / \mathrm{L}$ & $3,99 \mathrm{mmol} / \mathrm{L}$ \\
\hline 6 & $4,19 \mathrm{mmol} / \mathrm{L}$ & $4,14 \mathrm{mmol} / \mathrm{L}$ \\
\hline 7 & $3,74 \mathrm{mmol} / \mathrm{L}$ & $3,96 \mathrm{mmol} / \mathrm{L}$ \\
\hline 8 & $3,68 \mathrm{mmol} / \mathrm{L}$ & $4,33 \mathrm{mmol} / \mathrm{L}$ \\
\hline 9 & $3,36 \mathrm{mmol} / \mathrm{L}$ & $3,74 \mathrm{mmol} / \mathrm{L}$ \\
\hline 10 & $4,19 \mathrm{mmol} / \mathrm{L}$ & $4,22 \mathrm{mmol} / \mathrm{L}$ \\
\hline 11 & $4,11 \mathrm{mmol} / \mathrm{L}$ & $4,01 \mathrm{mmol} / \mathrm{L}$ \\
\hline 12 & $3,89 \mathrm{mmol} / \mathrm{L}$ & $4,09 \mathrm{mmol} / \mathrm{L}$ \\
\hline 13 & $4,07 \mathrm{mmol} / \mathrm{L}$ & $4,32 \mathrm{mmol} / \mathrm{L}$ \\
\hline 14 & $3,90 \mathrm{mmol} / \mathrm{L}$ & $4,21 \mathrm{mmol} / \mathrm{L}$ \\
\hline 15 & $3,94 \mathrm{mmol} / \mathrm{L}$ & $3,79 \mathrm{mmol} / \mathrm{L}$ \\
\hline 16 & $3,87 \mathrm{mmol} / \mathrm{L}$ & $4,07 \mathrm{mmol} / \mathrm{L}$ \\
\hline 17 & $3,97 \mathrm{mmol} / \mathrm{L}$ & $4,30 \mathrm{mmol} / \mathrm{L}$ \\
\hline 18 & $4,00 \mathrm{mmol} / \mathrm{L}$ & $4,54 \mathrm{mmol} / \mathrm{L}$ \\
\hline 19 & $3,91 \mathrm{mmol} / \mathrm{L}$ & $3,75 \mathrm{mmol} / \mathrm{L}$ \\
\hline 20 & $3,61 \mathrm{mmol} / \mathrm{L}$ & $3,64 \mathrm{mmol} / \mathrm{L}$ \\
\hline MEAN & $3,86 \mathrm{mmol} / \mathrm{L}$ & $4,05 \mathrm{mmol} / \mathrm{L}$ \\
\hline MIN & $3,36 \mathrm{mmol} / \mathrm{L}$ & $3,64 \mathrm{mmol} / \mathrm{L}$ \\
\hline MAX & 4,19 mmol/L & $4,54 \mathrm{mmol} / \mathrm{L}$ \\
\hline $\mathbf{S}$ & 0,2164 & 0,2367 \\
\hline
\end{tabular}


Tabel hasil pemeriksaan menunjukkan sebanyak $70 \%$ data sampel mengalami kenaikan kadar kalium yang sampelnya diambil menggunakan teknik pemasangan tourniquet yang tidak dilepaskan (14 data). Sebanyak 25\% sampel mengalami penurunan kadar kalium yang sampelnya diambil menggunakan teknik pemasangan tourniquet yang tidak dilepaskan (5 data). Sebesar 5\% sampel tidak mengalami perubahan kadar kalium meskipun diambil menggunakan dua teknik pemasangan tourniquet yang berbeda (1 data).

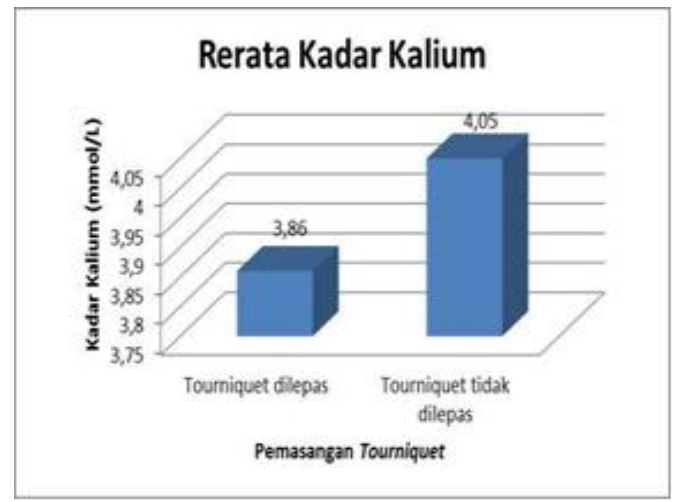

Gambar 1: Rerata Kadar Kalium

\section{b. Pembahasan}

Hasil pemeriksaan kadar kalium pada subyek penelitian, sebanyak 70\% sampel mengalami kenaikan kadar kalium pada perlakuan kedua yaitu dengan pengambilan sampel menggunakan teknik pemasangan tourniquet yang tidak dilepaskan. Uji $\mathrm{T}$ berpasangan (paired T-test) dilakukan pada data yang terdistribusi normal, dan terhadap data yang berhubungan satu sama lain. Tingkat kepercayaan yang digunakan dalam uji $\mathrm{T}$ berpasangan ini sebesar $95 \%$ dengan resiko terjadinya kesalahan sebesar 0,05 apabila $\mathrm{p}$ value $<0,05$ maka ada perbedaan terhadap kadar kalium yang diambil dengan dua teknik pemasangan tourniquet yang berbeda.

\begin{tabular}{lcccl}
\hline $\begin{array}{l}\text { Teknik } \\
\begin{array}{l}\text { Pemasangan } \\
\text { Tourniquet }\end{array}\end{array}$ & Mean & SD & P Value & Kesimpulan \\
\hline Dilepaskan & 3,86 & 0,216 & & \\
\hline Tidak dilepaskan & 4,05 & 0,236 & 0,003 & Ada perbedaan \\
\hline
\end{tabular}

\section{Tabel 2 Uji T Berpasangan}

Hal ini dapat disebabkan karena adanya perpanjangan waktu pembendungan yang meningkatkan tekanan intravena dan akibatnya terjadi hipoksia pada jaringan vasuler yang menyebabkan terjadinya infiltrasi molekul kecil serta cairan dari dalam lumen ke jaringan perifer (Serdar Muhittin et al., 2008). Hipoksia karena waktu stasis yang diperpanjang juga dapat menyebabkan elemen intraselular berinfiltrasi ke dalam 
plasma. Akibatnya kadar kalium salam sampel mengalami peningkatan yang berarti secara statistik.

Hasil ini sesuai dengan penelitian yang sudah dilakukan sebelumnya, menurut Lippi G et al (2005) penelitian ini menyebutkan bahwa penggunaan tourniquet pada tekanan $60 \mathrm{mmHg}$ selama 1 dan 3 menit akan menyebabkan perubahan signifikan pada kadar kalium serum. Pada penelitian tersebut sedikit terdapat perbedaan pada perlakuan dimana tourniquet dipertahankan selama satu dan tiga menit, sementara pada penelitian ini tourniquet dipertahankan hanya hingga vena dapat diakses dan hingga pengambilan darah mencapai volume yang diinginkan.

Clinical and Laboratory Standards Institute (CLSI) dalam Strasinger (2011) menyebutkan bahwa tourniquet sebaiknya segera dilepaskan segera setelah vena dapat diakses. Peningkatan hasil sebagai akibat perpanjangan waktu pembendungan dengan tourniquet ini menunjukkan bahwa teknik pemasangan tourniquet cukup berpengaruh dalam hasil akhir pemeriksaan kalium serum. Dengan ini dapat diambil kesimpulan bahwa teknik pengambilan yang pertama, dengan cara langsung melepas tekanan sphygmomanometer segera setelah vena dapat diakses, adalah cara terbaik untuk mendapatkan sampel darah dalam pemeriksaan kalium.

\section{KESIMPULAN}

Dari penelitian yang sudah dilakukan tentang "Perbedaan Teknik Pemasangan tourniquet terhadap Kadar Kalium Serum" dapat disimpulkan bahwa terdapat perbedaan kadar kalium yang diambil dengan menggunakan teknik pemasangan tourniquet yang dilepaskan dan menggunakan teknik pemasangan tourniquet yang tidak dilepaskan, dan sebaiknya penggunaan pembendung dalam proses pengambilan darah dilakukan dalam waktu sesingkat mungkin agar tidak mempengaruhi hasil pemeriksaan.

Untuk selanjutnya dapat dilakukan penelitian serupa untuk melihat pengaruh penggunaan pembendung (Tourniquet) terhadap analit lain, dan dengan memperhatikan waktu penggunaan pembendung tersebut. Berdasarkan penelitian ini maka sebaiknya para petugas pengambil sampel menggunakan tourniquet seminimal mungkin agar tidak mempengaruhi hasil pemeriksaan.

\section{DAFTAR PUSTAKA}

Arneson W, Brickell J (2007). Clinical Chemistry: A Laboratory Perspective. Philadelphia: F.A Davis Company.

Burtis C, Ashwood ER, Burns DE (eds) (2008). Tietz Fundamentals of Clinical Chemistry. Sixth editon. Missouri: Saunders Elsvier. 
Cengiz M, Ulker P, Meiselman HJ, Baskurt OK (2009). Influence of Tourniquet Application on Venous Blood Sampling for Serum Chemistry, Hematological Parameters, Leukocyte Activation and Erythrocyte Mechanical Properties. Clin Chem Lab Med, 47 (6):769-776.

Clinical Laboratory Improvement Amandement (2013). Dalam ASVCP TEa Guideline (Biochemistry).USA

Dahlan M.S. (2012). Langkah-Langkah Membuat Proposal Penelitian Bidang Kedokteran dan Kesehatan. Edisi 2. Jakarta: Sagung Seto

Guyton AC (2012). Fisiologi Manusia dan Mekanisme Penyakit. Edisi 3. Jakarta: EGC.

Kee JL (2007). Pedoman Pemeriksaan Laboratorium \& Diagnostik. Edisi 9. Jakarta: Penerbit Buku Kedokteran EGC.

Keputusan Menteri Kesehatan Republik Indonesia nomor 1792/MENKES/SK/XII/ 2010 tentang Pedoman Pemeriksaan Kimia Klinik

Kiswari R (2014). Hematologi dan Transfusi. Jakarta: Penerbit Erlangga

Lippi G, Salvagno GL, Montagnana M, Brocco G, Guidi GC (2005).Influence of Short

Term Venous Statis on Clinical Chemistry Testing.Clin Chem Lab Med, 43 (8), 869875.

Marlinda Novi PSH (2015). Perbedaan Kadar Glukosa Darah Puasa 1 Jam dan 2 Jam Setelah Asupan Permen pada Mahasiswa DIV Teknologi Laboratorium Medik Fakultas Ilmu Kesehatan Universitas Katolik Musi Charitas Palembang. Palembang, Universitas Katolik Musi Charitas Palembang. Skripsi

Medica Corp. (2014). Medica Easy Lyte Operator's Manual. USA: Bedford

Mulyono H (2010). Pemantapan Mutu Laboratorium Kimia Klinik. Dalam: Sukorini U., Dwi KN, Mohammad R., Bambang H.P.J (eds). Pemantapan Mutu Internal Laboratorium Klinik. Jogjakarta: Alfamedia. pp 85-89

Notoatmodjo S. (2012). Metodologi Penelitian Kesehatan. Jakarta: Rineka Cipta.

Peraturan Menteri Kesehatan Republik Indonesia No 43 Tahun 2013 Tentang Cara Penyelenggaraan Laboratorium Klinik yang Baik

Perhimpunan Dokter Spesialis Patologi Klinik Indonesia (2012). Modul Pelatihan Nasional Flebotomi Dasar bagi Analis Kesehatan. Edisi 2.

Sacher RA, Mc Pherson RA (2004). Pengaturan Asam-basa dan Elektrolit. Dalam: Tinjauan Klinis Hasil Pemeriksaan Laboratorium. Alih bahasa: Pendit, BU dan Wulandari B, Edisi 11. Jakarta: EGC, pp: 327-330

Serdar MA, et al (2008). Tourniquet Application Time during Phlebotomy and The Influence on Clinical Chemistry Testing; Is It Negligible?.Turkish Journal of Biochemistry. 33 (3), 85-88.

Sinaga H. (2011). Urinalisis. Palembang: Multi Sarana

Sunyoto D. (2012). Statistik Kesehatan. Jogjakarta: Nuha Medika

Sutoro (2014). Penyimpangan Hasil Pemeriksaan Kadar Elektrolit Darah ( $\mathrm{Na}+\mathrm{K}+, \mathrm{Cl}-)$ yang di Tampung dalam Tabung Vakum Baru dan Bekas. Semarang, Universitas Muhammadiyah Semarang. Skripsi.

Strasinger SK, Marjorie S. (2011). The Phlebotomy Textbook. Third Edition. Philadelphia: F.A. Davis Company.pp:178; 194; 226 
Wilson L.M. (2006). Gangguan Volume, Osmolalitas, dan Elektrolit Cairan. Dalam: Price S.A, Wilson L.M (eds). Patofisiologi: Konsep Klinis Proses Proses Penyakit. Jakarta: Penerbit Buku Kedokteran EGC.

Wolcott J, Schwartz A, Goodman C (2008). Laboratory Medicine: A National Status Report. The Lewin Group, 150.

Yaswir R, Ira F (2012). Fisiologi dan Gangguan Keseimbangan Natrium, Kaliun dan Klorida serta Pemeriksaan Laboratorium. Jurnal Kesehatan Andalas, 1(2), 80-85 